\title{
Residential Property Prices in Central, Eastern and Southeastern European Countries: Stocktaking of Data and a View on New Developments in Data Availability
}

\begin{abstract}
Residential property prices play an important role in many areas of economics and finance. They are used, for example, to determine the value of a major component of real wealth, as an indicator of financial stability risks stemming from residential property price gyrations, or to monitor inflation developments. However, the specific characteristics of residential property make primary data collection and index calculation difficult tasks. Against this background, the aim of this paper is to compare different residential property price indices in terms of price developments and methodologies for the ten Central, Eastern and Southeastern EU Member States (CESEE-10). In doing so, we focus on new developments in data availability for the CESEE-10, in particular the recent release of the Eurostat house price index (HPI). This index is a major step forward, providing improved EU-wide cross-country comparability of housing transaction prices. The comparison of the different data series with the new Eurostat index indicates some differences in the timing of local price peaks and the degree of price dynamics. Moreover, price movements diverged in some CESEE countries in the past two years. The comparison of the new Eurostat index to a price index that is purely based on asking prices exhibits a slightly lower correlation. Panel data research is set to benefit from Eurostat's compilation of national house price indices, while time series analysis will continue to rely on the longer series of national statistics for the time being.
\end{abstract}

JEL classification: C8, E3, P22

Keywords: Residential property prices, housing markets, Central, Eastern and Southeastern Europe

Residential property markets are local markets and therefore used to be considered to be mainly of national interest. In the same vein, property market crises were viewed as local turmoil with no major impact on other economies (e.g. the Swedish, Norwegian and Finnish housing market crisis in the second half of the 1980s and early 1990s). But in 2007-08, the turbulence that started in the U.S. housing and mortgage market turned into a major international economic and financial crisis, as it created massive cross-country spillovers via globalized financial markets and structured products.

When, in the wake of the recent distress in financial markets, the international community started to pay increasing attention to the monitoring of property price developments worldwide, huge information gaps became obvious. Upon recommendation of the Financial Stability Board (FSB) and the International Monetary Fund (IMF) to the G-20 finance ministers and central bank governors, the Bank for International Settlements (BIS) was assigned to collect and disseminate residential property price statistics to visualize the status quo of data coverage. ${ }^{2}$ It turned out that data availability and the methodologies for data collection vary to a great extent between countries.

\footnotetext{
Oesterreichische Nationalbank, Foreign Research Division, katharina.steiner@oenb.at. The author would like to thank Peter Backé, Zoltan Walko and Josef Schreiner (all OeNB) and Maximilian Mendel (Residential Advisors) for valuable comments.

2 This information has been available at www.bis.org since 2010.
} 
The next step would be to set up common international standards for property price statistics to enhance data quality and cross-country comparability. To date, this remains an open issue at the international level. Meanwhile, Eurostat started work on a Handbook on Residential Property Price Statistics to give practical guidance on setting up residential property price indices and improving their quality. In addition, Eurostat and national statistical institutes (NSIs) undertook a series of pilot projects to develop and compile housing price indices for owner-occupied housing $(\mathrm{OOH})$ in the framework of the Harmonised Index of Consumer Prices (HICP). A key outcome of these efforts is Eurostat's house price index. It was released in early 2013 and aims at raising the cross-country comparability of price data, at least for the 27 EU Member States, including the 10 Member States in Central, Eastern and Southeastern Europe (CESEE-10). ${ }^{3}$

The aim of this study is to (1) briefly discuss the general characteristics of residential property prices and important aspects related to data collection and data processing, (2) to show two different residential property price time series gathered by NSIs for the CESEE-10, (3) to compare these time series to the Eurostat residential property price time series as well as to discuss methodological differences and (4) to touch upon implications for future research that uses house prices.

\section{Characteristics of Residential Property Price Data}

Residential property prices can be used for different purposes: Consumers can use this information to decide whether to buy or to rent a home; experts can use them as a yardstick to measure real wealth, as a financial stability indicator, as input into the consumer price index or as an indicator of macroeconomic activity (Eurostat, 2013a). Each use may require the index to be based on specific primary data and calculation methodologies. For example, buyers and sellers of residential property need the residential property price index to be based on transaction prices to assess house price inflation. By contrast, an economist interested in measuring an economy's (real) housing wealth needs additional information on the housing "stock of non-transacted dwellings" (Eurostat, 2013a). These examples describe the two separate types of residential property price indices which can be distinguished: a price index based on the stock of residential property at a given point in time and an index for residential property sales during a particular period of time (Eurostat, 2013a). As current principal values of non-traded housing stock are mostly not available, reweighting of transaction price data is used to reflect the different mix of houses in the non-traded housing stock. ${ }^{4}$

In general, primary data vary according to geographical location and the point in time when they are measured during a house purchase process (e.g. asking price versus final transaction price). The data can be taken from different sources, e.g. real estate agencies, newspapers or property registers and tax offices. Each of them has advantages and disadvantages. Data taken from property registers often do not offer detailed information on qualitative characteristics of the property, and the

\footnotetext{
3 The CESEE-10 include Bulgaria, the Czech Republic, Estonia, Hungary, Latvia, Lithuania, Poland, Romania, Slovakia and Slovenia.

4 Eurostat's Handbook (Eurostat, 2013a) provides detailed information on these issues and related methodological aspects.
} 
indicated value of the property may be outdated or even incorrect. On the other hand, data taken from real estate agencies may only cover a certain type of residential property, and offer prices often overestimate the price of the real transaction. In addition, the composition of the types of properties sold can change over time and should not be interpreted as a price change (Eurostat, 2013a). Residential property transactions may also be very infrequent, particularly in countries with high rates of homeownership, such as in CESEE, which complicates the data compilation further (Hilbers et al., 2008).

Residential property markets are rather opaque and segmented, as the majority of residential properties is unique. It is therefore important to have information on quality characteristics of residential property, e.g. the size of the land the house sits on, location of the property, age, type (detached/semi-detached house, flat) and materials used (Eurostat, 2013b). As the quality of the property changes over time due to depreciation or renovation activities, the construction of price indices is even more difficult in comparison to typical price indicators of identical goods (Brunauer et al., 2012). Therefore, statisticians construct so-called constant quality indices, e.g. via hedonic regressions. ${ }^{5}$ In light of the different methods, Eurostat released its Handbook on Residential Property Price Indices in April 2013 (Eurostat, 2013a), which serves as a comprehensive guideline for collecting and processing residential property price data for statisticians.

In practice, limited availability of primary data (in terms of data frequency, coverage and quality characteristics) often comes into play and constrains the construction of different residential property price time series. In addition, price indices are published more often than nominal price time series. The former, however, do not give any indication of different price levels across geographical areas or different types of properties. Therefore, it is of importance to describe the characteristics of the data applied in detail and exercise caution in the interpretation of the data at hand, given the differences and difficulties in compiling.

\section{Residential Property Price Indices in CESEE: A Comparison}

In CESEE, most countries saw a strong rise in residential property prices until 2007-08, followed by a more or less severe contraction. Price increases partly reflected the catching-up process in the formerly state-controlled housing market. During the privatization process in the early 1990s, houses were often sold below market prices. The subsequent surge in house prices went along with, inter alia, (expectations of) rising household income, stronger demand for higher living standards, and - consequently - heightened indebtedness of households and increased lending to households in foreign currency (Huynh-Olesen et al., 2013).

In most CESEE countries, NSIs or the national central bank publish several residential property price series based on different primary data and property characteristics, such as prices for new and/or existing dwellings, flats or houses in different geographical areas, based on transaction or asking prices. Both the BIS and the ECB collect and disseminate residential property price statistics from these national sources; these collections give a good overview of the variety of

Other methods are described in detail in Eurostat (2013a). 
available time series ${ }^{6}$. Chart 1 shows two residential property price indices for the whole country and the capital city for each of the CESEE-10, ${ }^{7}$ which allow analyzing price volatility, but do not give an indication of the nominal price level. In Bulgaria the price index is available only for the whole country, and in Romania only for the capital city. The indices were selected on the basis of more or less common characteristics, but data availability also constrained the selection. Detailed information on the data characteristics and sources can be found in the annex (table A).

Nominal house prices in CESEE mostly peaked around 2007 and 2008, with the exception of Poland (2009) and Hungary (2011). But in contrast to the transaction price data shown in chart 1, market observers saw Polish housing prices decline already in late 2008. This discrepancy shows that data collection methods matter a lot: For example, the collection of transaction price data on the basis of notarial purchase contracts might be biased by late registrations of property purchases. Overall, the countries with the strongest cumulative price hikes up to the local price peak were also those with the strongest price decline afterwards, namely the Baltics, Bulgaria and Romania. Since 2009-10, prices have been on the rise again in some countries, mainly in Estonia and Latvia. In the other countries, prices were mainly flat or even declined somewhat further, also as a result of a decline in the number of housing transactions.

The comparison of the price index for the capital city and the index for the whole country reveals that the indices moved largely in parallel. Some difference in the timing of the local price peak and the degree of price dynamics can be identified, particularly in Hungary, Poland and Slovenia. In 2012, there was some divergence, as in Slovenia and Lithuania, prices for the whole country declined while capital city house prices increased. In Latvia, the price increase in the whole country seen recently was not as strong as the price increase in the capital city.

As far as the methodology used to compute the price indices is concerned, both indices are mainly based on transaction prices per square meter, except for the indices for Romania, Slovakia and Poland (REAS, national central bank and NSI, respectively). ${ }^{8}$ They comprise both new and existing dwellings. The data provided by the NSIs or national central banks are mostly also available via the ECB or BIS database.

\footnotetext{
The ECB provides publicly available data via its Statistical DataWarehouse (SDW). The BIS provides publicly available data at http://www.bis.org/statistics/pp.htm. The another's compilation of data definitions for the CESEE-10 is available upon request.

7 These residential property price indices were applied in the descriptive and empirical studies by Hildebrandt et al. (2012) and by Huynh-Olesen et al. (2013).

8 Asking (= offer) prices for the capital city are used in Romania and Poland due to a lack of long-term transaction price data. The same applies to house prices in the capital city in Slovakia. A comparison between transaction and asking price data shows broadly similar price movements over time in all CESEE-10 countries, but the magnitude of the price changes differs somewhat (Hildebrandt et al., 2012).
} 


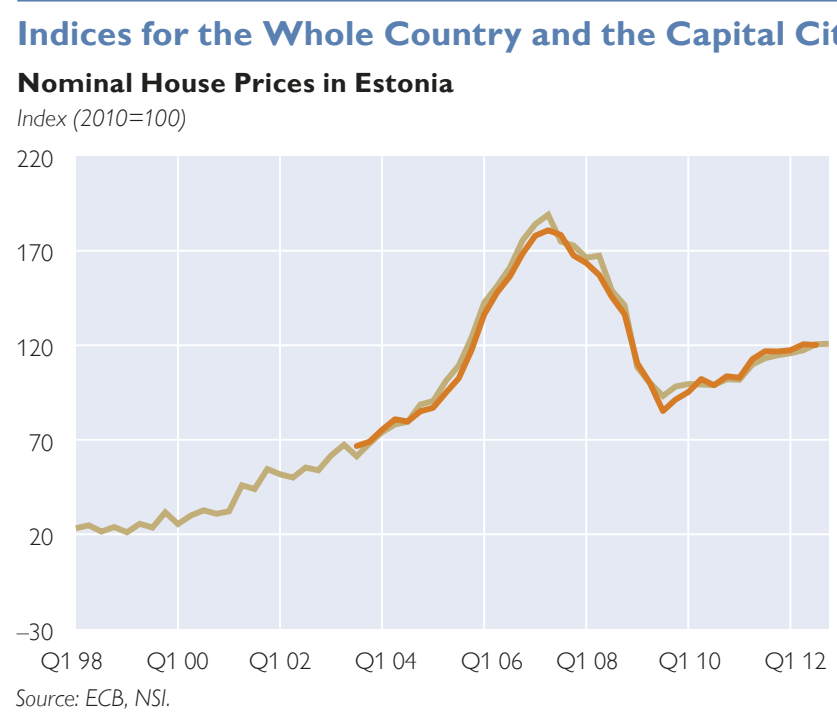

\section{Nominal House Prices in Lithuania}

Index (2010=100)

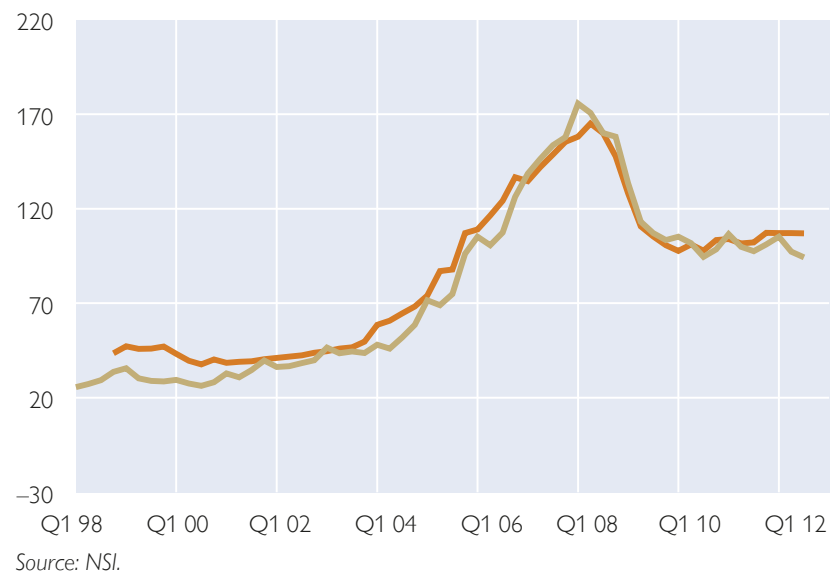

\section{Nominal House Prices in Poland}

Index (2010=100)

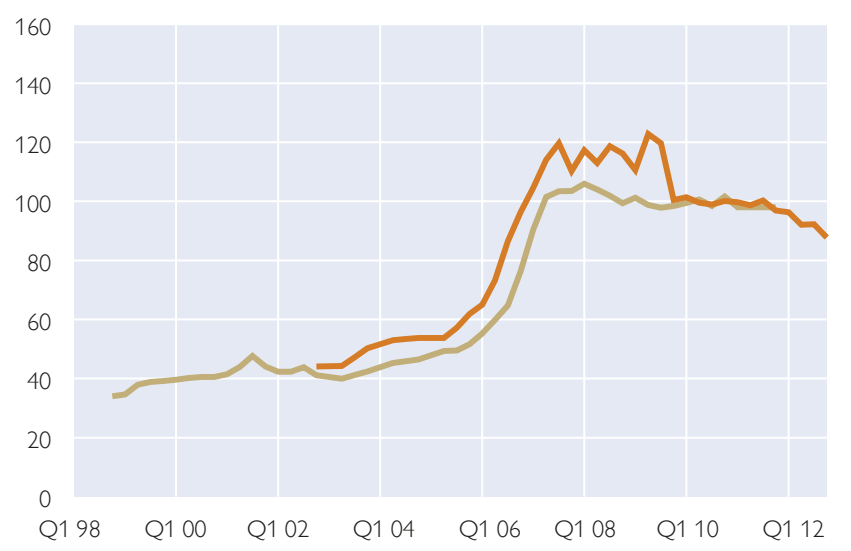
Source: BIS, NSI.

- House prices in the capital city

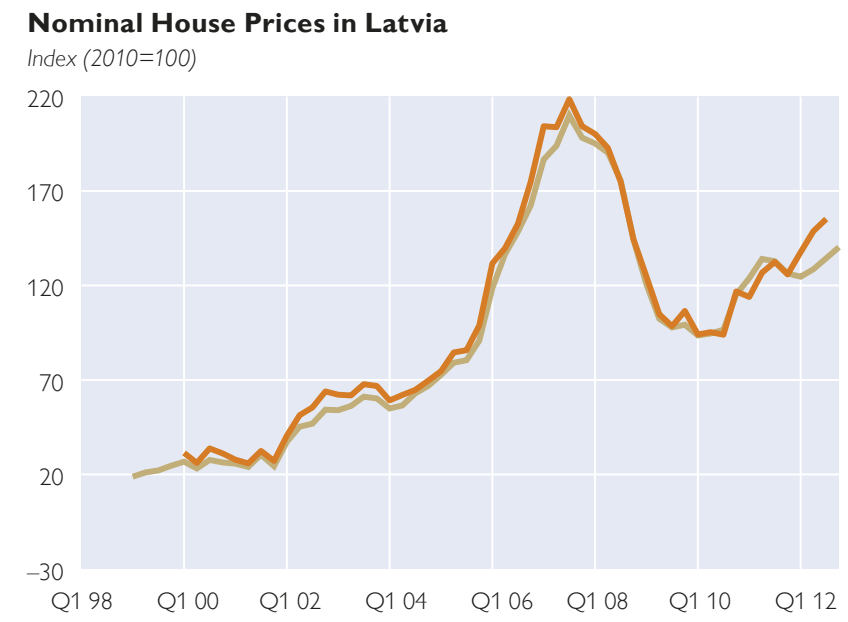

Source: $E C B, N S$.

Nominal House Prices in Bulgaria

Index (2010=100)

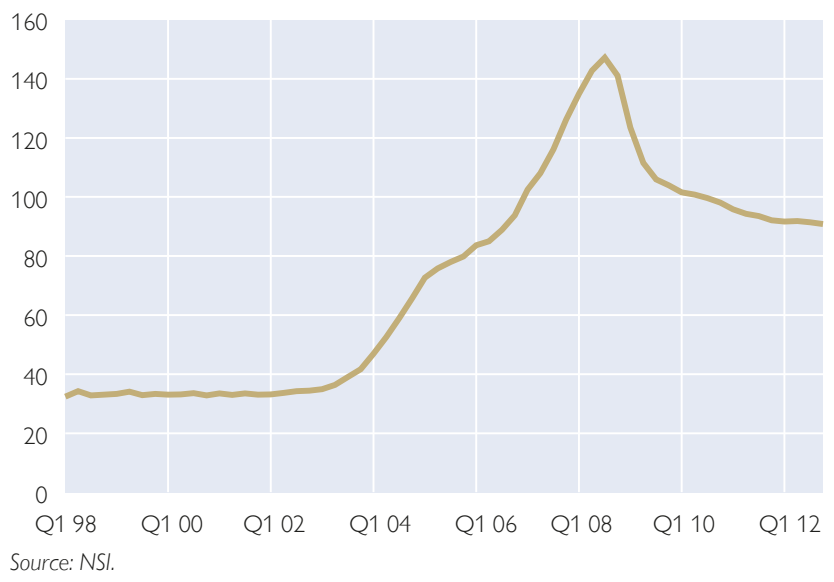

Nominal House Prices in Romania

Index (2010=100)

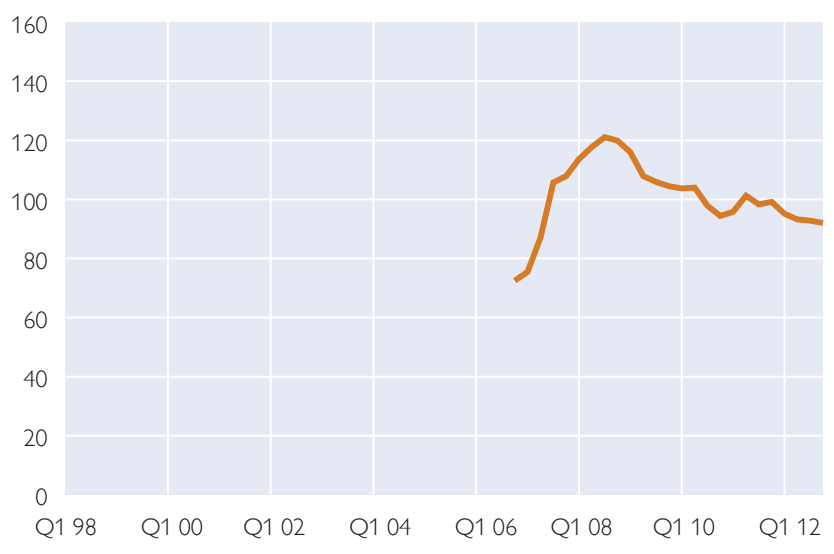
Source: REAS. 

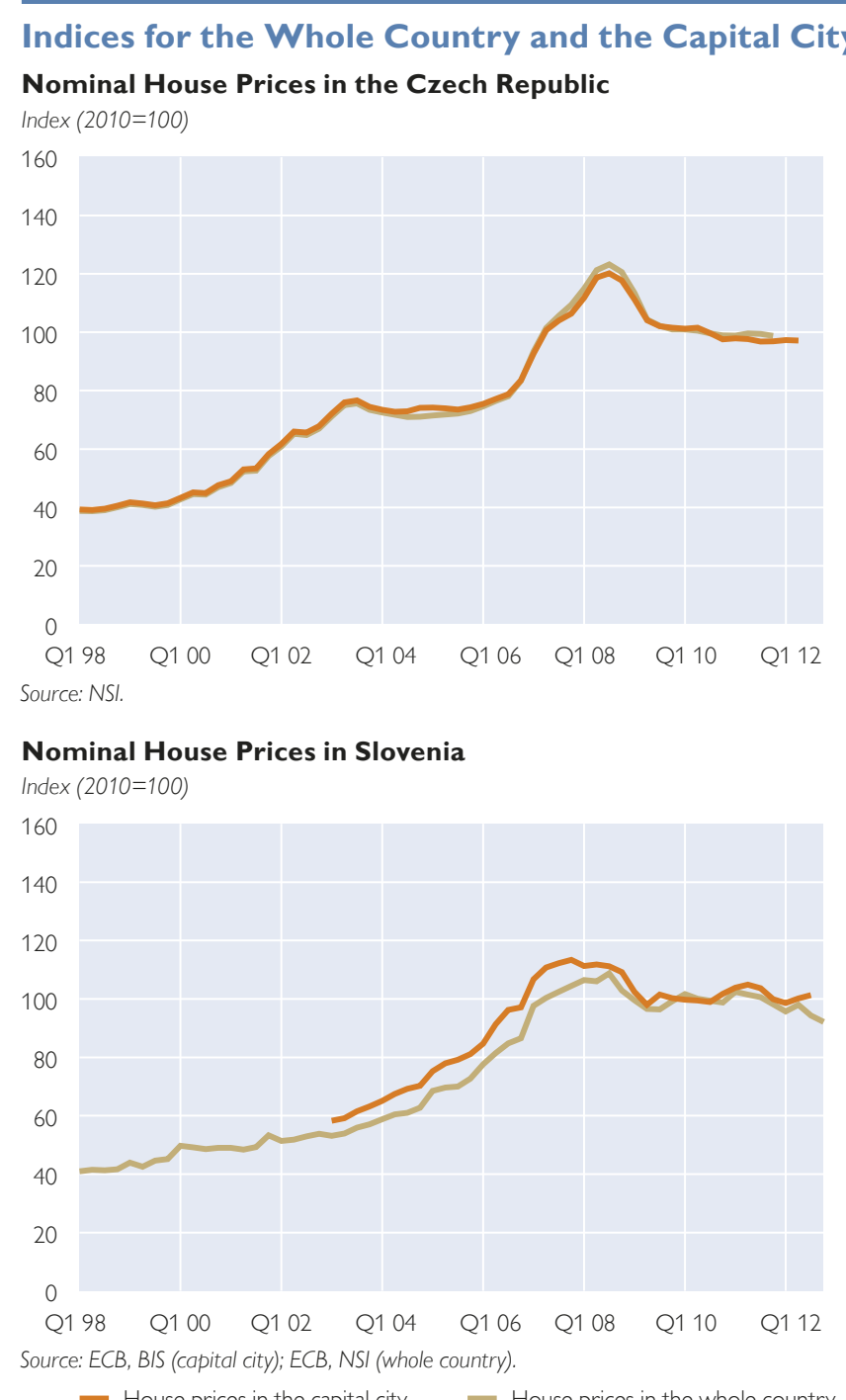

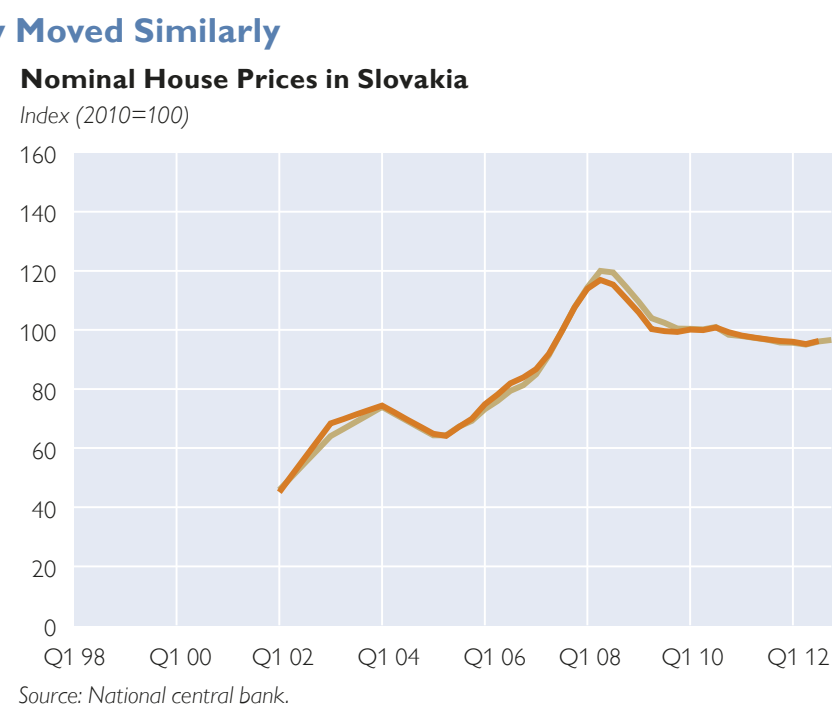

Nominal House Prices in Hungary

Index (2010=100)

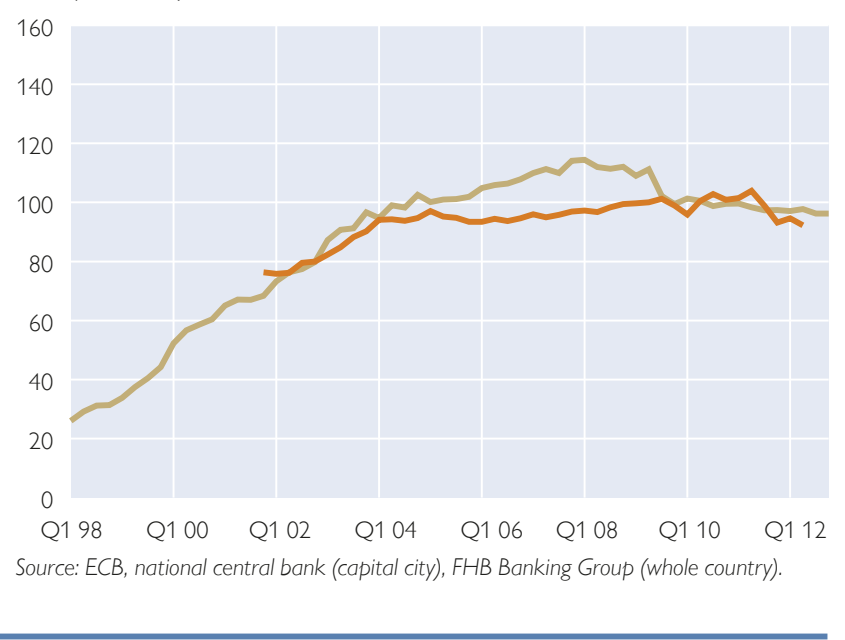

\section{Comparison of the Eurostat House Price Index with Other} Residential Property Price Indices

As the demand for high-quality and, particularly, cross-country comparable house price statistics increased during the past decade, Eurostat cooperated with the NSIs within the owner-occupied housing pilot project to set up a (largely) harmonized database, in the following referred to as the Eurostat house price index (HPI). It is a constant quality residential property price index to measure inflation in the residential property market. Eurostat collects the national data provided by the NSIs, which should be based on broadly comparable methodologies, and conducts additional quality checks (Eurostat, 2013b). The Eurostat HPI is available for all 27 EU Member States (except Poland) as well as Iceland and Norway on a quarterly basis. So far, there are no data available for Croatia. Eurostat also computes country group aggregates for the euro area and the EU-27 on the basis of these time series. 
As far as the methodology used to calculate the Eurostat HPI is concerned, the primary data are more similar than those on which the indices shown in chapter 1 are based. According to Eurostat (2013b), the Eurostat HPI captures quarterly changes in average transaction prices of "all kinds of residential property purchased by households (flats, detached houses, terraced houses, etc.), both new and existing." Owner-built dwellings are excluded, whereas the land component of the residential property is included; the methodology thus follows the gross acquisition approach. The Eurostat index measures pure price changes as it is adjusted for changes in quality. However, the number and type of determining characteristics of the properties can change over time; therefore these factors are also controlled for. ${ }^{9}$ But the Eurostat HPI too is conditional on data availability as shown by the example of Bulgaria, for which the data do not exactly match the theoretical description of what the Eurostat HPI should comprise: The Eurostat HPI corresponds entirely to the price index shown in chapter 1, which, however, comprises only existing flats instead of all kinds of residential property as required under the definition of the Eurostat HPI. Nevertheless, it is a good proxy given that the data are based on prices in district centers of 27 big cities and as no other data are (publicly) available. Eurostat (2013b) admits that there is "a variety of data sources both for weights (National Account data, Household Budget Survey data, Construction Statistics, etc.) and prices (administrative data, bank (mortgage) data, construction companies, real estate agents, etc.)" used in compiling the data set. In addition, the price concept may vary (e.g. transaction versus asking prices). Another shortcoming of the Eurostat HPI is that there is no detailed information on the price segments and specific property types the price is based on. In addition, it is an average price, which clearly shows trends, but does not make it possible to identify exceptional local or regional price developments. Despite the fact that proxies are used in view of scarce data availability, a clear advantage of the Eurostat HPI is that Eurostat monitors and assesses the soundness of the methodologies applied and the adherence to its recommendations at the national level (Eurostat, 2013b). This enhances cross-country comparability, although for the time being the relative shortness of the Eurostat time series constrains the empirical analysis, in particular time series analysis.

Chart 2 shows the Eurostat HPI for the CESEE-10. Similar to the price indices shown in chapter 2, the Eurostat data also suggest that the countries with the highest growth of house prices were those with the strongest price correction thereafter (namely the Baltics). But the time series only start in the first quarter of 2005 and do not capture the period of price increases in the late 1990s and the first half of the 2000s. ${ }^{10}$ Nevertheless, the chart shows that the cumulated price increase from 2005 to the local price peak was more or less fully reversed by the price decline until 2010 in all countries. Since then, prices have picked up again in Estonia, Latvia and - to some extent - in Lithuania and Slovenia. In Romania, residential property prices have been on a declining path since end-2009, while prices in Slovenia have been decreasing since 2011. In most countries, however, house price volatility moderated in the course of 2011 and 2012.

9 Details can be found in the Technical Manual on Owner-Occupied Housing - House Price Indices.

${ }^{10}$ The time series for Bulgaria are too short and do not cover the period of the price increase in the years 2004 to 2008 . 


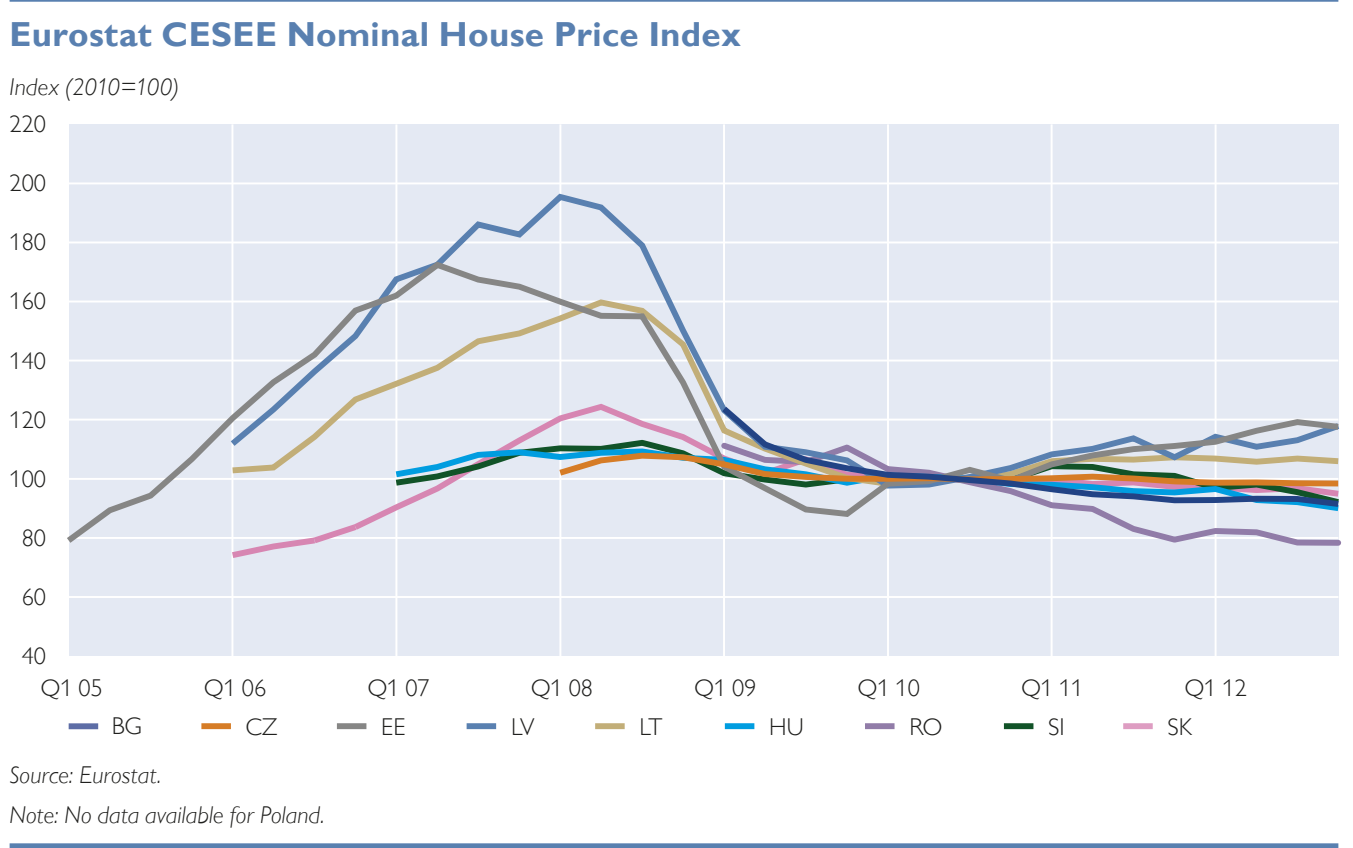

Comparing the price developments according to the Eurostat HPI with price growth according to the national price indices for the capital city and the whole country as described in chapter 2 reveals that all indices show similar price movements. The correlation coefficient of the Eurostat HPI and the two price indices confirms this proposition (table 1, columns 1 and 2). The correlation is high for all countries, ranging between 0.71 for Slovenia (transaction prices for the whole country) and 1.0 for Bulgaria (transaction prices in the capital city). Hungary is an exception, showing almost no correlation of the Eurostat HPI with the price index

Table 1

Correlation of the Eurostat House Price Index with Selected Other Indices

\begin{tabular}{lr|r|r} 
& \multicolumn{3}{l}{ Correlation with the residential property price index for } \\
\cline { 2 - 4 } & the whole country & the capital city & \\
\cline { 2 - 4 } Based on & transaction prices & transaction prices & asking prices \\
Czech Republic & 0.96 & 0.96 & 0.90 \\
Slovakia & 0.90 & 0.99 & 0.97 \\
Poland & n.a. & n.a. & n.a. \\
Hungary & 0.91 & 0.03 & 0.83 \\
Slovenia & 0.71 & 0.79 & 0.80 \\
Estonia & 0.97 & 0.98 & 0.99 \\
Latvia & 0.95 & 0.92 & 0.93 \\
Lithuania & 0.97 & 0.98 & 0.94 \\
Bulgaria & 1.00 & n.a. & 0.99 \\
Romania & n.a. & 0.83 & 0.83
\end{tabular}
for the capital city because prices did not move in parallel from the beginning of 2007 to end-2009. Comparing the correlation coefficients of the different time series with the Eurostat HPI per country does not show great differences in the strength of the correlation. The correlation of the Eurostat HPI with the index based on asking prices in the capital city is the only one to show somewhat lower coefficients for some countries (table 1, column 3). These asking prices are taken from REAS, a private sector real estate advisory company. The data are mainly taken from the primary market and partly based on local market monitoring and expert judgment of the primary market; this method of collection is 


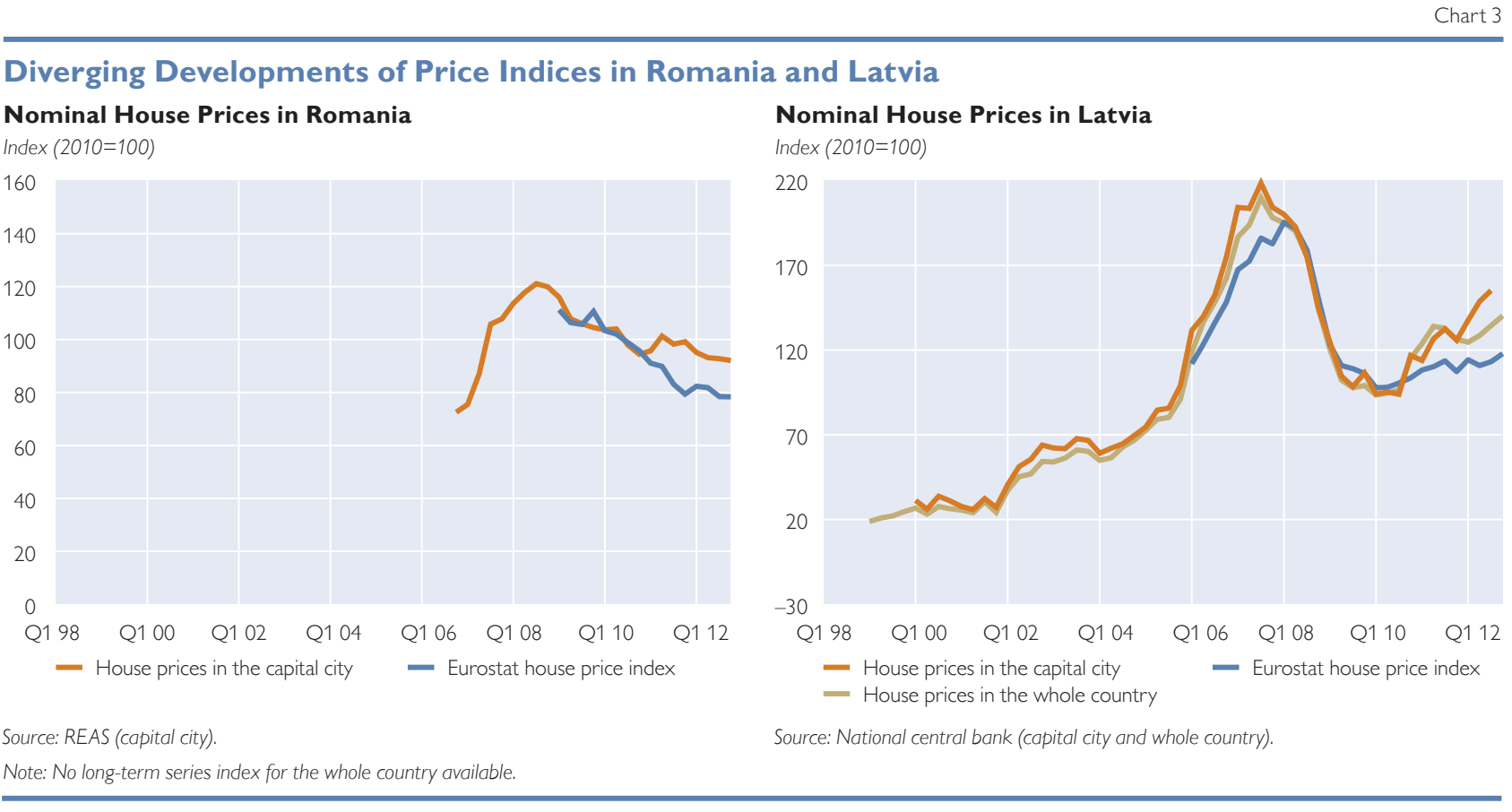

slightly different from the data collection methods applied for the other time series shown above.

On the one hand, the high correlation of the data strengthens the validity of the national time series described in section 2. On the other hand, the similarity might not be surprising because Eurostat's HPI is based on data material compiled by the same NSIs.

Despite the high overall correlation, the price developments according to the different indices slightly diverged in the past three years, to some extent in Lithuania and Slovenia, and particularly so in Romania and Latvia (chart 3). In Romania, the two indices have diverged particularly strongly since 2011. While the Eurostat HPI points to a continued strong price decrease, the other house price time series increased somewhat in the first half of 2011 before slightly declining again according to the national statistics. In Latvia, the indices show differences in the level of growth and the timing of the price peak. While the national price indices indicate the nominal price peak at end-2007, the Eurostat HPI shows that the price peak took place a couple of quarters later. The divergent development of the indices since 2011 is even more striking. While house prices in the capital city rose much more strongly than those in the whole country, the Eurostat HPI increased at a much slower pace. These examples show that it is important to conduct robustness checks applying different residential property price time series in empirical analyses of housing markets.

Supplementing chart 3, table B in the annex shows the correlation coefficients for two subsample periods, namely the pre- and post-crisis period, for all countries to help find out whether the correlation changes over time. Evidence is mixed in this respect, but pre- and post-crisis correlation coefficients often do not differ substantially. The correlation coefficient was higher before the crisis compared to the post-crisis period for some countries (for transaction prices in the whole country in Latvia, Slovakia and Slovenia; for transaction prices in the capital city in 
Latvia and Hungary), whereas in other countries it increased thereafter (for transaction prices in the whole country in Hungary and in the capital city in Slovenia). Caution is warranted in the interpretation of the results for some countries as the availability of pre-crisis data is very limited or there are no data available at all, for instance for Bulgaria and Romania (see table B in the annex).

\section{Summary}

The comparison of different price indices reveals similar residential property price developments in CESEE over time. Measuring the correlation coefficients of the newly released Eurostat HPI and the national residential property price indices for the whole country and the capital city, which are mainly based on transaction prices, confirm this finding. However, the data show diverging results for the timing of the local price peak and the degree of price dynamics. Most recently, the movement of the Eurostat HPI and the respective two national price indices diverged to a greater extent, particularly in Latvia and Romania.

Supplementing the analysis of transaction price indices, asking prices for dwellings in the capital city provide a different picture of the market. Nevertheless, they show broadly the same price movements over time, again with some variation in the timing of the price peak and the degree of price dynamics. The correlation of the asking prices in the capital city with the Eurostat HPI is somewhat lower compared to the correlation of the Eurostat HPI with the transaction prices, given the different data collection methods for transaction and asking price data.

Overall, the fundamental difficulties in collecting primary house price data persist. But the efforts at the international level to harmonize the various methods are an important step forward. They are particularly valuable for cross-country panel data studies and allow overcoming the problem of too short time series for longitudinal time series analysis. Also, short-term series might fail to reflect broad movements of house prices (Maeso-Fernandez et al., 2004). In general, given the still limited availability of long-term series, the quality of research using housing prices can be assured only by detailed reporting of data and methodologies applied and by supplementing the findings with additional residential property market data (e.g. building permits, residential property investment).

While the situation concerning house price data in CESEE EU Member States has improved, much less progress has been seen with respect to commercial real estate prices. In fact, there appear to be no country-wide price indices available for commercial real estate. This makes it difficult to monitor price dynamics in this market segment and, as a consequence, to assess e.g. financial stability risks stemming from the commercial real estate market. 


\section{References}

Brunauer, W., W. Feilmayr and K. Wagner. 2012. A New Residential Property Price Index for Austria. In: Statistiken - Daten und Analysen Q3/12. 90-102.

Eurostat. 2013a. Handbook on Residential Property Prices Indices (RPPIs). Eurostat Methodologies \& Working Papers. http://epp.eurostat.ec.europa.eu/cache/ITY_OFFPUB/KS-RA-12-022/ EN/KS-RA-12-022-EN.PDF (retrieved on July 25, 2013).

Eurostat. 2013b. Housing price statistics. Reference Metadata in Euro SDMX Metadata Structure (ESMS). http://epp.eurostat.ec.europa.eu/cache/ITY_SDDS/EN/prc_hps_esms.htm (retrieved on July 25, 2013).

Eurostat. 2013c. http://epp.eurostat.ec.europa.eu/portal/page/portal/hicp/methodology/hps/ house_price_index (retrieved on July 25, 2013).

Hilbers, P., A. W. Hoffmaister, A. Banjerji and H. Shi. 2008. Residential Property Price Developments in Europe: A Comparison. IMF Working Paper 211.

Hildebrandt, A., R. Martin, K. Steiner and K. Wagner. 2012. Residential Property Markets in CESEE EU Member States. In: Focus on European Economic Integration Q1/12. 8-30.

Huynh-Olesen, D. T., K. Steiner, A. Hildebrandt and K. Wagner. 2013. Residential Property Prices in Central, Eastern and Southeastern European Countries: The Role of Fundamentals and Transition-Specific Factors. In: Focus on European Economic Integration Q2/13. 52-76.

Maeso-Fernandez, F., C. Osbat and B. Schnatz. 2004. Towards the estimation of equilibrium exchange rates for CEE acceding countries: methodological issues and a panel cointegration perspective. ECB Working Paper 353. April. 


\section{Annex}

\section{Detailed Information on Nominal House Price Indices in the CESEE-10 (2010=100)}

\begin{tabular}{|c|c|c|c|c|c|c|c|c|c|c|}
\hline \multirow[b]{2}{*}{$\begin{array}{l}\text { Coun- } \\
\text { try }\end{array}$} & \multicolumn{5}{|c|}{ House prices for the whole country } & \multicolumn{5}{|c|}{ House prices for the capital city } \\
\hline & $\begin{array}{l}\text { Geogra- } \\
\text { phical area }\end{array}$ & $\begin{array}{l}\text { Type of } \\
\text { dwellings }\end{array}$ & $\begin{array}{l}\text { Statistical } \\
\text { concept }\end{array}$ & $\begin{array}{l}\text { Time span of } \\
\text { original time } \\
\text { series }\end{array}$ & $\begin{array}{l}\text { Primary } \\
\text { source }\end{array}$ & $\begin{array}{l}\text { Geogra- } \\
\text { phical area }\end{array}$ & $\begin{array}{l}\text { Type of } \\
\text { dwellings }\end{array}$ & $\begin{array}{l}\text { Statistical } \\
\text { concept }\end{array}$ & $\begin{array}{l}\text { Time span of } \\
\text { original time } \\
\text { series }\end{array}$ & $\begin{array}{l}\text { Primary } \\
\text { source }\end{array}$ \\
\hline Bulgaria & $\begin{array}{l}\text { Big cities } \\
\text { (27 district } \\
\text { centers) }\end{array}$ & $\begin{array}{l}\text { Existing } \\
\text { flats }\end{array}$ & $\begin{array}{l}\text { Transaction } \\
\text { price per } \\
\text { square meter }\end{array}$ & $\begin{array}{l}\text { Q1 1997- } \\
\text { Q4 2012, } \\
\text { quarterly data }\end{array}$ & NSI & n.a. & n.a. & n.a. & n.a. & n.a. \\
\hline $\begin{array}{l}\text { Czech } \\
\text { Republic }\end{array}$ & $\begin{array}{l}\text { Whole } \\
\text { country }\end{array}$ & $\begin{array}{l}\text { Existing } \\
\text { flats }\end{array}$ & $\begin{array}{l}\text { Transaction } \\
\text { price per } \\
\text { square meter }\end{array}$ & $\begin{array}{l}\text { Q1 2004- } \\
\text { Q4 2012, } \\
\text { quarterly data }\end{array}$ & NSI & Capital city & $\begin{array}{l}\text { Existing } \\
\text { flats }\end{array}$ & $\begin{array}{l}\text { Transaction } \\
\text { price per } \\
\text { square meter }\end{array}$ & $\begin{array}{l}\text { Q1 1998- } \\
\text { Q2 2012, } \\
\text { quarterly data }\end{array}$ & NSI \\
\hline Estonia & $\begin{array}{l}\text { Whole } \\
\text { country }\end{array}$ & $\begin{array}{l}\text { Existing } \\
\text { and new } \\
\text { flats }\end{array}$ & $\begin{array}{l}\text { Transaction } \\
\text { price per } \\
\text { square meter }\end{array}$ & $\begin{array}{l}\text { Q3 2003- } \\
\text { Q4 2012, } \\
\text { quarterly data }\end{array}$ & NSI & Capital city & $\begin{array}{l}\text { Existing } \\
\text { and new } \\
\text { flats }\end{array}$ & $\begin{array}{l}\text { Transaction } \\
\text { price per } \\
\text { square meter }\end{array}$ & $\begin{array}{l}\text { Q3 2003- } \\
\text { Q1 2013, } \\
\text { quarterly data }\end{array}$ & NSI \\
\hline Hungary & $\begin{array}{l}\text { Whole } \\
\text { country }\end{array}$ & n.a. & $\begin{array}{l}\text { Transaction } \\
\text { price per } \\
\text { square meter }\end{array}$ & $\begin{array}{l}\text { Q1 1998- } \\
\text { Q4 2012, } \\
\text { quarterly data }\end{array}$ & $\begin{array}{l}\text { FHB } \\
\text { Banking } \\
\text { Group }\end{array}$ & Capital city & $\begin{array}{l}\text { Existing } \\
\text { dwellings }\end{array}$ & $\begin{array}{l}\text { Transaction } \\
\text { price per } \\
\text { square meter }\end{array}$ & $\begin{array}{l}\text { Q4 2001- } \\
\text { Q2 2012, } \\
\text { quarterly data }\end{array}$ & $\begin{array}{l}\text { National } \\
\text { central } \\
\text { bank }\end{array}$ \\
\hline Latvia & $\begin{array}{l}\text { Whole } \\
\text { country }\end{array}$ & $\begin{array}{l}\text { Existing } \\
\text { and new } \\
\text { flats }\end{array}$ & $\begin{array}{l}\text { Transaction } \\
\text { price per } \\
\text { square meter }\end{array}$ & $\begin{array}{l}\text { Q1 2000-- } \\
\text { Q4 2012, } \\
\text { quarterly data }\end{array}$ & NSI & Capital city & $\begin{array}{l}\text { Existing } \\
\text { and new } \\
\text { flats }\end{array}$ & $\begin{array}{l}\text { Transaction } \\
\text { price per } \\
\text { square meter }\end{array}$ & $\begin{array}{l}\text { Q1 2000- } \\
\text { Q1 2013, } \\
\text { quarterly data }\end{array}$ & NSI \\
\hline $\begin{array}{l}\text { Lithua- } \\
\text { nia }\end{array}$ & $\begin{array}{l}\text { Whole } \\
\text { country }\end{array}$ & $\begin{array}{l}\text { Existing } \\
\text { and new } \\
\text { flats }\end{array}$ & $\begin{array}{l}\text { Transaction } \\
\text { price per } \\
\text { square meter }\end{array}$ & $\begin{array}{l}\text { Q4 1998- } \\
\text { Q4 2012, } \\
\text { quarterly data }\end{array}$ & NSI & Capital city & $\begin{array}{l}\text { Existing } \\
\text { and new } \\
\text { flats }\end{array}$ & $\begin{array}{l}\text { Transaction } \\
\text { price per } \\
\text { square meter }\end{array}$ & $\begin{array}{l}\text { Q4 1998- } \\
\text { Q2 2012, } \\
\text { quarterly data }\end{array}$ & NSI \\
\hline Poland & Big cities & $\begin{array}{l}\text { Existing } \\
\text { flats }\end{array}$ & $\begin{array}{l}\text { Transaction } \\
\text { price per } \\
\text { square meter }\end{array}$ & $\begin{array}{l}\text { Q4 2002-- } \\
\text { Q4 2012, } \\
\text { quarterly data, } \\
\text { index calcula- } \\
\text { ted from price- } \\
\text { level data }\end{array}$ & NSI & Capital city & $\begin{array}{l}\text { Existing } \\
\text { flats }\end{array}$ & $\begin{array}{l}\text { Asking price } \\
\text { per square } \\
\text { meter }\end{array}$ & $\begin{array}{l}\text { Q4 2002- } \\
\text { Q1 2013, } \\
\text { quarterly data, } \\
\text { index calcula- } \\
\text { ted from price- } \\
\text { level data }\end{array}$ & $\begin{array}{l}\text { Private } \\
\text { organiza- } \\
\text { tion, BIS }\end{array}$ \\
\hline Romania & n.a. & n.a. & n.a. & n.a. & n.a. & Capital city & $\begin{array}{l}\text { Existing } \\
\text { and new } \\
\text { dwellings }\end{array}$ & $\begin{array}{l}\text { Asking price } \\
\text { per square } \\
\text { meter }\end{array}$ & $\begin{array}{l}\text { Q4 2006- } \\
\text { Q4 2012, } \\
\text { quarterly data }\end{array}$ & REAS \\
\hline Slovakia & $\begin{array}{l}\text { Whole } \\
\text { country }\end{array}$ & $\begin{array}{l}\text { Existing } \\
\text { and new } \\
\text { dwellings }\end{array}$ & $\begin{array}{l}\text { Asking price } \\
\text { per square } \\
\text { meter }\end{array}$ & $\begin{array}{l}\text { Q1 2002-- } \\
\text { Q4 2012, } \\
\text { quarterly data }\end{array}$ & $\begin{array}{l}\text { National } \\
\text { central } \\
\text { bank }\end{array}$ & Capital city & $\begin{array}{l}\text { Existing } \\
\text { and new } \\
\text { dwellings }\end{array}$ & $\begin{array}{l}\text { Asking price } \\
\text { per square } \\
\text { meter }\end{array}$ & $\begin{array}{l}\text { Q1 2002- } \\
\text { Q3 2012, } \\
\text { quarterly data, } \\
\text { index calcula- } \\
\text { ted from price- } \\
\text { level data }\end{array}$ & $\begin{array}{l}\text { National } \\
\text { central } \\
\text { bank }\end{array}$ \\
\hline Slovenia & $\begin{array}{l}\text { Whole } \\
\text { country }\end{array}$ & $\begin{array}{l}\text { Existing } \\
\text { dwellings }\end{array}$ & $\begin{array}{l}\text { Transaction } \\
\text { price per } \\
\text { square meter }\end{array}$ & $\begin{array}{l}\text { Q1 2003-- } \\
\text { Q4 2012, } \\
\text { quarterly data }\end{array}$ & NSI & Capital city & $\begin{array}{l}\text { Existing } \\
\text { flats }\end{array}$ & $\begin{array}{l}\text { Transaction } \\
\text { price per } \\
\text { square meter }\end{array}$ & $\begin{array}{l}\text { Q1 2003-- } \\
\text { Q1 2013, } \\
\text { quarterly data }\end{array}$ & NSI \\
\hline
\end{tabular}

Source: ECB, BIS, author's compilation based on Hildebrandt et al. (2012) and Huynh-Olesen et al. (2013).

Note: For the purpose of the empirical analysis in Huynh-Olesen et al. (2013), some of the time series for the whole country were extrapolated backward on the basis of other available price indices. For Bulgaria and Romania, the time series were used interchangeably for the whole country and the capital city given the lack of other longer time series. For more details see the annex in Huynh-Olesen et al. (2013). 
Correlation of the Eurostat House Price Index with Selected Other Indices in the Pre- and Post-Crisis Periods

\begin{tabular}{|c|c|c|c|c|c|c|c|c|c|c|c|c|}
\hline \multirow{4}{*}{ Based on } & \multicolumn{12}{|c|}{ Correlation with the residential property price index for } \\
\hline & \multirow{2}{*}{\multicolumn{4}{|c|}{$\begin{array}{l}\text { the whole country } \\
\text { transaction prices }\end{array}$}} & \multicolumn{8}{|c|}{ the capital city } \\
\hline & & & & & \multicolumn{4}{|c|}{ transaction prices } & \multicolumn{4}{|c|}{ asking prices } \\
\hline & \multicolumn{2}{|c|}{ pre-crisis } & \multicolumn{2}{|c|}{ post-crisis } & \multicolumn{2}{|c|}{ pre-crisis } & \multicolumn{2}{|c|}{ post-crisis } & \multicolumn{2}{|l|}{ pre-crisis } & \multicolumn{2}{|c|}{ post-crisis } \\
\hline Czech Republic & 1.00 & (2) & 0.99 & (15) & 1.00 & $(2)$ & 0.97 & $(17)$ & 1.00 & $(2)$ & 0.93 & (19) \\
\hline Slovakia & 0.94 & $(10)$ & 0.74 & (19) & 0.99 & $(10)$ & 0.97 & $(18)$ & 0.99 & (7) & 0.97 & (19) \\
\hline $\begin{array}{l}\text { Poland } \\
\text { Hungary }\end{array}$ & $\begin{array}{r}\text { n.a. } \\
0.54\end{array}$ & $\begin{array}{l}(0) \\
(6)\end{array}$ & $\begin{array}{r}\text { n.a. } \\
0.91\end{array}$ & $\begin{array}{l}\text { n.a. } \\
(19)\end{array}$ & $\begin{array}{r}\text { n.a. } \\
0.58\end{array}$ & $\begin{array}{l}\text { n.a. } \\
(6)\end{array}$ & $\begin{array}{l}\text { n.a. } \\
0.22\end{array}$ & $\begin{array}{l}\text { n.a. } \\
(17)\end{array}$ & $\begin{array}{r}\text { n.a. } \\
-0.69\end{array}$ & $\begin{array}{r}\text { n.a. } \\
\text { (6) }\end{array}$ & $\begin{array}{r}\text { n.a. } \\
0.87\end{array}$ & $\begin{array}{l}\text { n.a. } \\
\text { (18) }\end{array}$ \\
\hline Slovenia & 0.95 & (6) & 0.79 & (19) & 0.72 & (6) & 0.91 & $(18)$ & 0.98 & (6) & 0.79 & (19) \\
\hline Estonia & 0.99 & $(14)$ & 0.97 & (19) & 0.99 & (14) & 0.97 & $(18)$ & 0.89 & (7) & 0.96 & (19) \\
\hline Latvia & 0.96 & $(10)$ & 0.89 & (19) & 0.93 & $(10)$ & 0.84 & $(18)$ & -0.21 & (7) & 0.94 & (19) \\
\hline Lithuania & 0.98 & $(10)$ & 0.96 & $(18)$ & 0.99 & $(10)$ & 0.99 & (18) & 0.63 & (7) & 0.96 & (19) \\
\hline Bulgaria & n.a. & $(0)$ & 0.99 & $(16)$ & n.a. & n.a. & n.a. & n.a. & n.a. & n.a. & 0.99 & $(16)$ \\
\hline Romania & n.a. & (0) & n.a. & n.a. & n.a. & n.a. & n.a. & n.a. & n.a. & n.a. & 0.83 & (16) \\
\hline
\end{tabular}

Source: Author's calculations.

Note: The nominal house price peak occured in the years 2007-08 in most countries (except Hungary (Q2 2011) and Poland (Q2 2009)). For reasons of simplicity, the two sub-samples representing the pre- and post-crisis period were divided in Q2 2008 starting/ending at the first/last available data point (see table $A$ in the annex). Figures in brackets indicate the number of observations available per period. 